\title{
Convective Thin-layer Drying Characteristics of Sesame Seed
}

\author{
O.U. Dairo ${ }^{1, a}$ and T.M.A. Olayanju ${ }^{1}$ \\ ${ }^{1}$ Department of Agricultural Engineering, Federal University of Agriculture, Abeokuta. P.M.B 2240. \\ Ogun State, Nigeria. \\ austeveo@yahoo.com. ,dusteveo@gmail.com (corresponding author)
}

[Date received: 28 May 2011. Date accepted: 25 August 2012]

Keywords: Sesame seed, Artificial drying, Thin layer, Modeling, Non-Linear Regression.

\begin{abstract}
Fundamental information on drying and re-wetting characteristics of agricultural seeds is required in the design and aeration systems as well as in the prediction of drying rate using various mathematical models. Thin-layer drying experiments were conducted using air-ventilated oven to simulate the artificial drying at various moisture contents of sesame seed (6.9 to $18.2 \% \mathrm{w} . \mathrm{b})$ at three drying temperatures of 40,50 and $60^{\circ} \mathrm{C}$. Five drying models were evaluated for the thin-layer data. The Page equation fitted the data best, where selection of the best model was obtained by comparing the coefficient of determination $\left(\mathrm{R}^{2}\right)$, the standard error of moisture content (SEM) and mean relative percent error (e) between the experimental and estimated values. The drying rate of sesame seed under drying conditions increased with increased temperature of drying $\left(40\right.$ to $\left.60{ }^{\circ} \mathrm{C}\right)$ and initial moisture content of seed ( 6.9, 11.5 and $18.2 \% \mathrm{w} . \mathrm{b})$. The parameters " $\mathrm{K}$ " of the Page model increased with increase in temperature, while, parameter "n" decreased with temperature increase and increased with increase in moisture content of seed. The effective diffusivity was found to be $2.32 \times 10-11 \mathrm{~m}^{2} \mathrm{~s}^{-1}$.
\end{abstract}

\section{Introduction}

Sesame seed (Sesamum orientale. $\mathbf{L}$ ) is an agricultural crop of growing importance in Nigeria that a national workshop was organized to discuss the prospect of exploiting the seed. Sesame is known as till, gingerly or simsim elsewhere in the world but its local name in Nigeria is benniseed. The seeds are small, ovate, slightly flattened at the bottom and weighs between $2-4 \mathrm{~g}$ per 1000 seeds. It is rich in protein content (19-25\%), oil content (44\%) and a good source of high quality edible oil [1] The seed is usually harvested at moisture contents of between $15-20 \%$ (w.b) and this has to be reduced significantly through drying before further processing. Bulk drying or aeration is usually carried out in deep beds; however simulation models assume a series of thin layer for proper dryer design and evaluation. Fundamental information on drying and rewetting characteristics of seed is required for designing near ambient drying and aeration systems.

Thin-layer drying information on seeds has been reportedly used in various computer-based deepbed drying models [2] Mathematical models, which fall into three categories, namely theoretical, semi-theoretical and empirical, have been used to describe thin layer drying process of food products [3],[4]. The Exponential (Newton) model, Page model, the modified Page model (Page I and II), the Henderson and Pabis model, the Thomson model, and the Wang and Singh model are among the most frequently used [5]. There have been many studies on thin layer drying of agricultural grains and leaves [6],[7],[8],[9],[10],[11],[12]. However, there is little information available on the drying characteristics of sesame seed at various moisture contents. Therefore, the objective of this study was to conduct thin-layer drying tests on sesame seed at different air temperatures and initial moisture contents, and determine a suitable thin-layer drying equation, which fits the data and describes the drying behaviour. 
Thin-Layer drying equations. Mathematical models that describe drying mechanisms of grain and food can present the best temperature and moisture information on agricultural crops during the drying process [13]. The comprehensive review of some of the equations is reported in detail by Jayas et al. [14]. Table 1 shows some of the available models used to represent thin-layer drying. Equations (1) to (5) in Table 1 have been used widely in the literature to describe thin-layer drying and rewetting behaviour of grains and oilseeds. They were therefore fitted to the experimental data for sesame seed drying in the current study. Several researchers have successfully reported the adequate representation of these models [8], [15], [16], [17].

Table 1 Thin Layer drying model tested for drying and rewetting of sesame seed

\begin{tabular}{llr}
\hline Model Name & Model Equation* & Equation No \\
\hline Newton & $M R=\exp ^{(-k t)}$. & $(1)$ \\
Page & $M R=\exp ^{\left(-k t^{n}\right)}$. & (3) \\
Henderson and Pabis & $M R=a \exp ^{(-k t)}$. & (4) \\
Logarithmic & $M R=a \exp ^{(-k t)}+c$. & (5) \\
Midilli-Kucuk & $M R=a \exp ^{\left(-k t^{n}\right)}+b t$.
\end{tabular}

* Hii et al[ 16]

The drying constants in thin-layer drying equations are usually related to experimental variables and have been severally reported to be dependent on experimental variable conditions [18],[19].

\section{Materials and Methods}

Thin-layer drying apparatus: The thin layer drying apparatus consisted of a Gallenkhamp 200v series oven with three separated tray sections ventilated with air at the same temperature and airflow rate. The average air temperature for each tray section was determined by a digital thermometer (Model Pronto Plus, Thermo-Electric Instruments, Saddle Brook, NJ) with a resolution of $\pm 0.1^{\circ} \mathrm{C}$. Dew point temperature was monitored at the air inlet section using a dry and wet bulb thermometer (Model Hygro-M1, General Eastern Instruments Inc., Watertown, MA) with a resolution of \pm 0.1 ${ }^{\circ} \mathrm{C}$. The sample trays had $24 \times 24 \mathrm{~cm}$ inside dimensions made of $2 \mathrm{~cm}$ thick aluminum frames with wire mesh screen fastened at the base to hold the sesame seeds. The mass of seeds and tray was measured with an electronic balance (Model Mettler PE1600, Mettler Instruments Corporation, Zurich, Switzerland) with a resolution of $\pm 0.01 \mathrm{~g}$.

Sample preparation and drying test procedure: Sesame seeds were obtained from the open market in Benue State, Nigeria. The initial moisture content was determined to be $6.9 \%$ (w.b). All seeds were manually cleaned to remove all foreign matter including broken seeds, chaffs and stones. Seeds at this initial moisture content were taken as the dried sample. In the case of rewetting, the seeds were conditioned to the desired moisture content level by adding calculated quantities of distilled water and mixing for several hours according to the method of Tabatabaee et al. [18]. All samples (dried and rewetted) were then kept in sealed plastic bags in a refrigerator at least $48 \mathrm{~h}$ for moisture content equilibration. The seeds were then stored at $5^{\circ} \mathrm{C}$ until used. Samples were brought out of the refrigerator for about $12 \mathrm{~h}$ before use to allow the samples to properly thaw and equilibrate with environmental conditions.

Samples with initial moisture contents of 6.9, 11.5, and $18.2 \%$ (w.b) in triplicate, were spread on trays, which were placed in the oven. Prior to putting trays in the oven, empty trays were weighed and $30 \mathrm{~g}$ of sesame seeds were uniformly spread over each tray to form a one kernel thick layer. Prior to starting the tests, the unit was left running at least $2 \mathrm{~h}$ to stabilize the air conditions. The 
mass of the tray with grains was recorded every ten minutes for the first one hour and every $30 \mathrm{~min}$ thereafter until the mass was within $\pm 0.01 \mathrm{~g}$ between two successive readings. The moisture content at this point was taken as the equilibrium moisture content. The time to reach equilibrium ranged from 3 to $4 \mathrm{~h}$ depending on the air conditions. The initial and final moisture contents of the grain were measured using the oven-drying method in which $10 \mathrm{~g}$ of the grains of sesame were dried at $130{ }^{\circ} \mathrm{C}$ for $6 \mathrm{~h}$ as recommended by Young et al.[20] for oil seeds with high oil contents. The change of the grain moisture content, with time, was calculated from the mass change data.

Data analysis: The experimental drying and rewetting data of sesame seed were fitted to the five equations presented in Table 1 using Non-Regression Analysis of Datafit 9.1[21]. and parameters for each equation were determined. The observed and predicted moisture contents were compared and statistically analyzed to determine the best-fit equation. The suitability of the equations was evaluated using the mean relative percent error (e), standard error of moisture content (SEM) and coefficient of determination $\left(\mathrm{R}^{2}\right)$. The mean relative percent error $(\mathrm{e})$ is defined as

$$
e=\frac{\sum\left(M_{m}-M_{p}\right)}{N}
$$

where

$\mathrm{M}_{\mathrm{m}}=$ measured moisture content (\% w.b.),

$\mathrm{M}_{\mathrm{p}}=$ predicted moisture content $(\%$ w.b.) and

$\mathrm{N}=$ number of observations.

The values of the parameters were back-substituted into the model to estimate moisture content at any time, $t$. The best-fit equation was then used to correlate the effects of temperature and initial moisture content over the entire range of thin-layer drying data.

\section{Results and Discussion}

The results of the statistical analysis of the models are presented in Table 2. The Page model had the lowest values of the mean relative percent error $(e)$ and standard error of moisture $(S E M)$ ranging from 0.0025 to 0.0037 and $1.04 \times 10^{-2}$ to $2.29 \times 10^{-2}$, respectively, while the $R^{2}$ value ranged from 0.975 to 0.988 . These statistical parameters were calculated for all conditions and models. The model that best described the thin layer drying characteristics is the one that gives the highest $R^{2}$, and lowest standard error of estimates and $e$ values [11],[22]. Therefore, for further analysis of data, only Page's equation was used. The Page model had been satisfactorily found to adequately describe drying characteristics of various crops [23]. 
Table 2 Non Linear Regression Parameters and Regression Statistics of thin-layer drying and rewetting of sesame seed at $6.9 \%$ moisture content

\begin{tabular}{|c|c|c|c|c|c|c|}
\hline \multirow[b]{2}{*}{ Regression Statistics } & \multirow[b]{2}{*}{$\begin{array}{l}\text { Tempe } \\
\text { rature } \\
\left({ }^{\circ} \mathrm{C}\right)\end{array}$} & \multicolumn{5}{|c|}{ Models } \\
\hline & & Page & $\begin{array}{l}\text { Midilli- } \\
\text { Kucuk }\end{array}$ & $\begin{array}{l}\text { Logarith } \\
\text { mic }\end{array}$ & $\begin{array}{l}\text { Henderson } \\
\text { and Pabis }\end{array}$ & Newton \\
\hline Coefficient of Determination $\left(\mathrm{R}^{2}\right)$ & 40 & 0.988 & 0.952 & 0.948 & 0.932 & 0.898 \\
\hline $\begin{array}{l}\text { Standard Error of Moisture } \\
\text { Content (SEM) } \times 10^{-2}\end{array}$ & & 1.411 & 2.145 & 2.538 & 2.584 & 3.562 \\
\hline Mean Relative Percent Error (e) & & 0.0037 & 0.0045 & 0.0050 & 0.0051 & 0.0075 \\
\hline Coefficient of Determination $\mathrm{R}^{2}$ & 50 & 0.985 & 0.957 & 0.943 & 0.942 & 0.910 \\
\hline $\begin{array}{l}\text { Standard Error of Moisture } \\
\text { Content (SEM) } \times 10^{-2}\end{array}$ & & 1.041 & 2.095 & 2.125 & 2.512 & 3.812 \\
\hline Mean Relative Percent Error (e) & & 0.0029 & 0.0039 & 0.0042 & 0.00499 & 0.0080 \\
\hline Coefficient of Determination $\mathrm{R}^{2}$ & 60 & 0.975 & 0.953 & 0.939 & 0.941 & 0.925 \\
\hline $\begin{array}{l}\text { Standard Error of Moisture } \\
\text { Content (SEM) } \times 10^{-2}\end{array}$ & & 2.294 & 2.315 & 2.411 & 2.687 & 4.258 \\
\hline Mean Relative Percent Error (e) & & 0.0025 & 0.0041 & 0.0042 & 0.0051 & 0.0080 \\
\hline
\end{tabular}

Drying parameters of Page's equation: The parameters of the Page's equation were estimated using the regression technique of Datafit 9.1[21]. Values of these parameters $(K$ and $n)$ are as shown in Table 3 for all temperatures and moisture contents used in the study. Parameter $\mathrm{k}$ was found to increase with temperature from 40 to $60{ }^{\circ} \mathrm{C}$ more significantly but reduced slightly with increased moisture content. The second parameter, $n$ was also found to decrease with increased drying temperature and increased with initial moisture content values as observed in Table 3.

Table 3 Estimated values of $K$ and $n$ parameters for Page Model

\begin{tabular}{cccc}
\hline \multirow{2}{*}{ Temperature } & $\begin{array}{c}\text { Moisture } \\
\text { content(\% w.b })\end{array}$ & $K(\mathrm{x} \mathrm{10})$ & $n$ \\
\hline 40 & 6.9 & 2.421 & 1.037 \\
& 11.5 & 1.820 & 1.079 \\
& 18.2 & 1.263 & 1.138 \\
\hline 50 & 6.9 & 6.550 & 0.856 \\
& 11.5 & 4.550 & 0.917 \\
& 18.2 & 4.331 & 0.929 \\
\hline 60 & 6.9 & 8.371 & 0.779 \\
& 11.5 & 8.155 & 0.812 \\
& 18.2 & 7.992 & 0.822 \\
\hline
\end{tabular}

Effect of temperature and initial moisture content: Figures $1 \mathrm{a}$ and $\mathrm{b}$ show the typical effect of drying temperatures on thin layer drying of sesame seed at the three initial moisture contents studied. The plot showed that the rate of moisture loss decreased as the elapsed time increased (Figures 1a, b) at both moisture levels until equilibrium was reached. It was observed that the drying curve consists in an initial fast reduction in moisture (first phase), followed by a falling rate period with the absence of any marked constant rate phase. This observation is inconsonance with the findings of Khazaei [24], on the natural drying of sesame seed, and other researchers such as 
Kashaninejad et al.[25]. The result suggests that diffusion is the most likely physical mechanism governing the moisture movement in sesame seed and this appears to be in agreement with past studies on drying of various food products. It could also be explained that at the beginning of

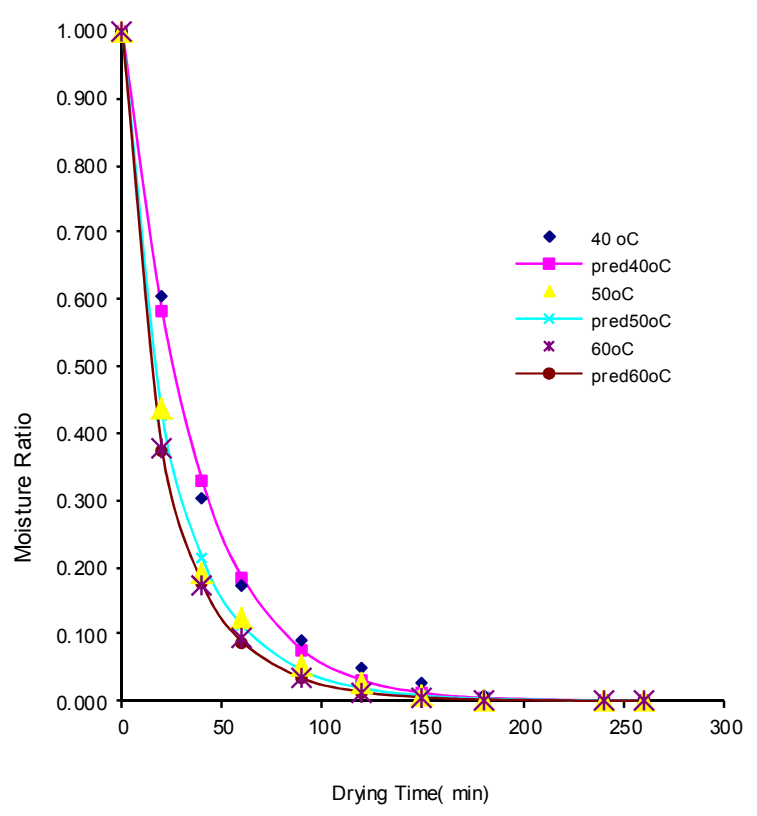

Fig 1a: Drying curve of Sesame seed at moisture content of $18.3 \%$ (w.b) and dry ing temperatures of 40,50 and $60{ }^{\circ} \mathrm{C}$.

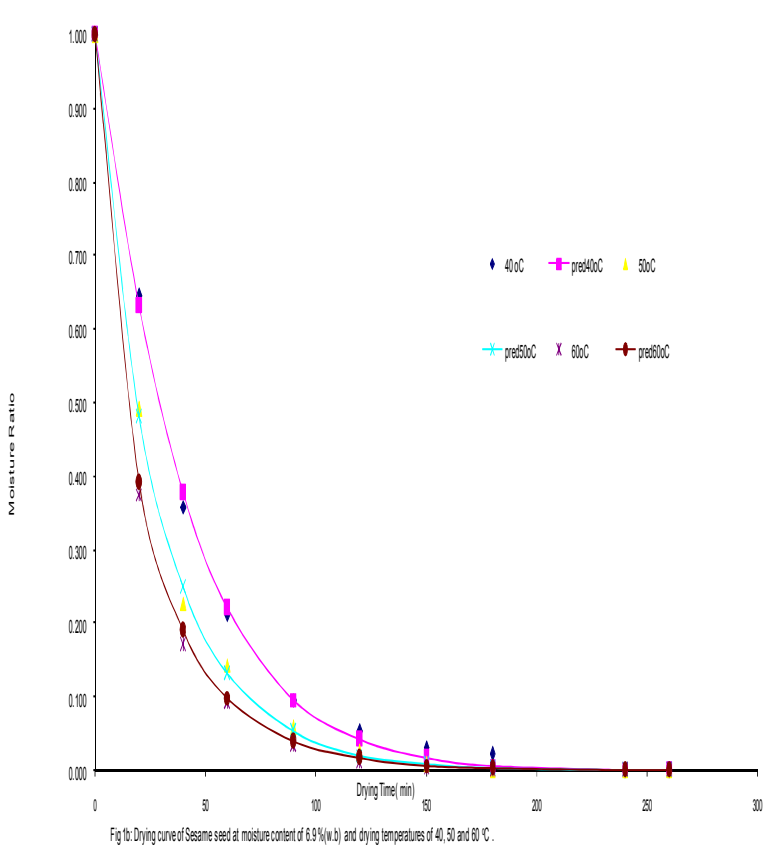

drying, the rate of drying was controlled by free water on the surface or outer layers of seeds. As the drying time increased, the drying rate further decreased indicating that water was no longer free; the water in the seeds was now held by molecular adsorption and capillary condensation. It can therefore, be considered a diffusion-controlled process, in which the rate of moisture removal is limited by diffusion of moisture from inside to the surface of the product. Previous studies have also showed that drying biological material is a diffusion-controlled process and may be represented by the Fick's law [8],[16],[18].

There was increased drying rate with increased temperature from 40 to $60{ }^{\circ} \mathrm{C}$. The drying rate at 40 ${ }^{\circ} \mathrm{C}$ was generally lower, with a marked difference between it and the other temperatures. This could probably be explained that the seed required heating to a level before the heat transfer will reach the core water and trigger the diffusion process. At this low temperature the rate of heat transfer might have been slower compared to other temperature levels, hence the wide gap in the curve of $40{ }^{\circ} \mathrm{C}$ and the other two temperatures investigated. It can be observed from Figures $1 \mathrm{a}$ and $1 \mathrm{~b}$ that moisture ratio decreased exponentially with time. The difference between moisture ratios increased gradually at the commencement of drying and the time to reach equilibrium moisture content decreases with increased temperature. Thus, the effect of temperature on drying rate can be established for sesame seed. This is in consonance with observations reported for shelled yellow corn [17], melon [7], diced cassava cubes [15] and fever leaves [8] among other researchers .

The typical effect of initial moisture content on the drying rate at all temperature levels studied is shown in Figures $2 a$ and $2 b$. The drying rate increased with increased initial moisture content. This may be attributed to the availability of more water at the surface for evaporation at high moisture levels and higher drying rates are expected to occur at the initial stage because of the presence of more surface water. At longer drying times less water is available and moisture movement is better controlled by diffusion as reported earlier. Similar observations have been made by other researchers [8],[16],[18]. 


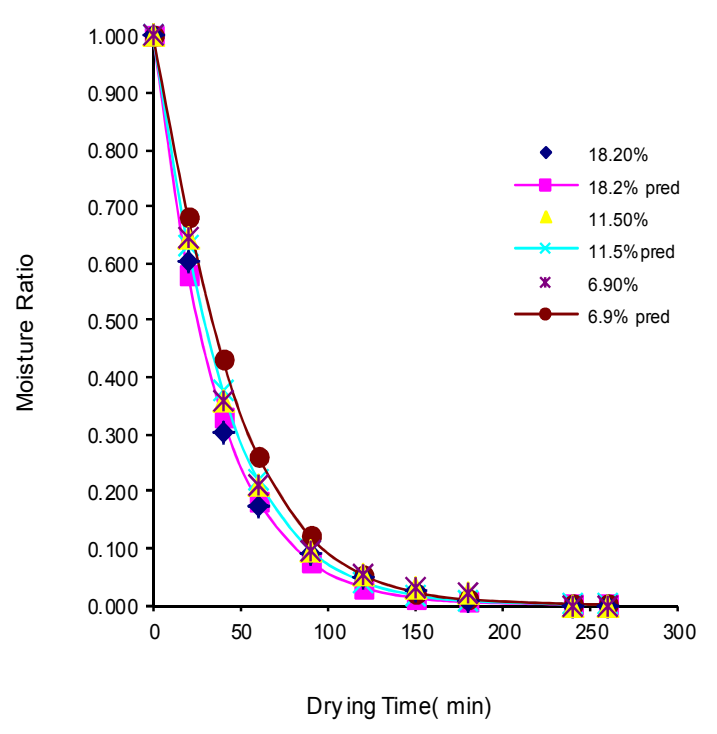

Fig 2a: Dry ing Curve of Sesame seed at $40^{\circ} \mathrm{C}$ with initial moisture content values of $6.9,11.5$ and $18.2 \%$ (w.b)

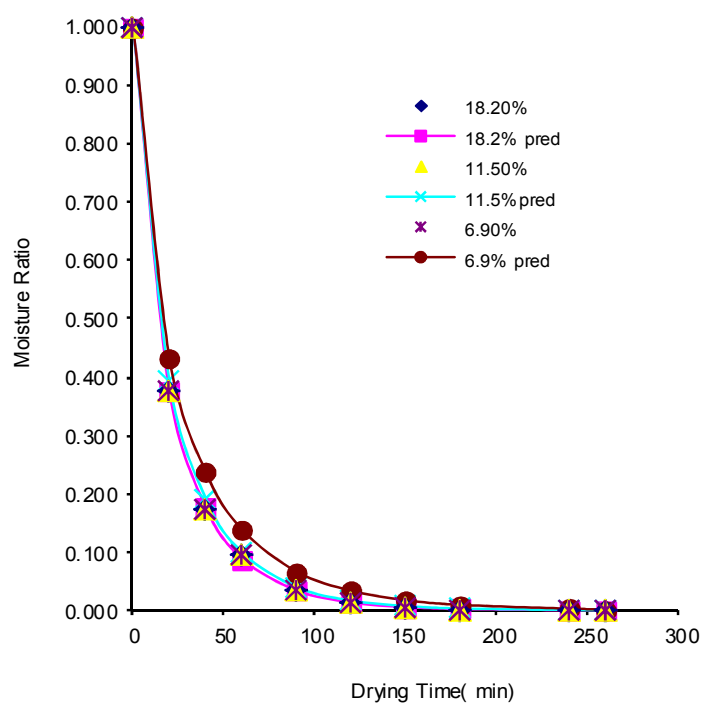

Fig 2b. Dry ing Curve of Sesame seed at $80^{\circ} \mathrm{C}$ with initial moisture content values of $6.9,11.5$, and $18.2 \%$ (w.b)

Effective diffusivity determination: With the assumptions of moisture migration being by diffusion with negligible shrinkage and constant diffusion coefficients, the Fick's second law can be used to describe the drying behaviour of agricultural products [26]. The analytical solution for long drying periods in logarithmic form for an infinite flat shaped material, simplified for only the first term, is given by

$$
\ln \frac{m_{t}}{m_{o}}=\ln \frac{8}{\pi^{2}}-\frac{\pi^{2} D_{e f f} t}{4 H^{2}}
$$

Drying of many food products, such as wheat [27], chestnuts [28], hull-less seed pumpkin [29] and pistachio nuts [25] have been successfully predicted using Fick's second law. The diffusivity given by the slope of Equation (9) is obtained by plotting experimental data in terms of natural logarithm of moisture ratio against drying time. The effective diffusivity was found to be $2.32 \times 10^{-11} \mathrm{~m}^{2} \mathrm{~s}^{-1}$. The value was however lower than the value obtained for forced convectional drying $\left(3.11 \times 10^{-11}\right.$ $\mathrm{m}^{2} \mathrm{~s}^{-1}$ ) and higher than $1.1 \times 10^{-11} \mathrm{~m}^{2} \mathrm{~s}^{-1}$ for natural convective drying of sesame seed obtained by Khazaei and Daneshmandi [30]. The differences might be due to the sphere shape configuration and the oven used in the present study. An infinite flat shaped configuration of Fick's Law exposed to air on both sides was assumed in this study. However the diffusivity value obtained was within the general range of between $10^{-9}$ and $10^{-11}$ for food and agricultural crops [31], [32].

\section{Conclusion}

The effects of temperature and initial moisture content were investigated on drying and rewetting characteristics of sesame. The drying rate increased with increased temperature and moisture content. Five thin layer drying equations were used to assess the goodness-of-fit to the experimental data. Page's equation was found to give the best fit with the highest $R^{2}$ values, lowest Standard Error of Moisture $(S E M)$ and mean relative percent error $(e)$ values. The parameters " $K$ " of the Page model increased with increase in temperature, while, parameter " $n$ " decreased with temperature increase and increased with increase in moisture content of seed. The effective diffusivity obtained from Fick's model was $2.32 \times 10^{-11} \mathrm{~m}^{2} \mathrm{~s}^{-1}$ assuming an infinite flat seed. 


\section{References}

[1] E.A. Weiss, Oil seed crops, Tropical Agriculture Series. Longman, London, 1983.

[2] S. Pabis, D.S. Jayas and S. Cenkowski, Grain Drying: Theory and Practice, John Wiley \& Sons Inc., New York, NY, 1998.

[3] A. Midilli, H. Kucuk and Z.A. Yapar, New model for single-layer drying. Drying Technology 20 (7) (2002) 1503 - 1513.

[4] P.C. Panchariya, D. Popovic and A.L. Sharma, Thin-layer modeling of black tea drying process, Journal of Food Engineering 52 (2002) 349 - 357.

[5] E.K. Akpinar, Y. Bicer and A. Midilli, Modeling and experimental study on drying of apple slices in a convective cyclone dryer. Journal of Food Process Engineering 26 (6): (2003) 515 -541 .

[6] E.K. Akpinar and Y. Bicer, Mathematical modeling and experimental study on thin-layer drying of strawberry, International Journal of Food Engineering 2 (1) (2006) 1 - 17.

[7] O.O. Ajibola, Thinlayer drying of melon seed, Journal of Food Engineering. 9 (1989) 305320.

[8] O.P. Sobukola and O.U. Dairo, Modeling drying kinetics of fever leaves(ocimen viride) in a convective hot air drier., Nigerian Food Journal 25 (1) (2007) 145 - 153.

[9] O.P. Sobukola, O.U. Dairo, L.O. Sanni, A.V. Odunewu and B.O. Fafiolu, Thinlayer drying process of some leafy vegetables under open sun drying. Food science and Technology International 13 (1) (2007) $35-40$.

[10] M.A. Karim and M.N.A. Hawlader, Drying characteristics of banana: Theoretical and experimental validation, Journal of Food Engineering 70 (2005) 35 - 45.

[11] I. Doymaz, Convective air drying characteristics of thin layer carrots, Journal of Food Engineering 61 (2004) 359 - 364.

[12] DI. oymaz, Drying behaviour of green beans, Journal of Food Engineering 69 (2005) 161 165 .

[13] M. Parti, Selection of mathematical models for drying grain in thin-layers, Journal of Agricultural Engineering Research 54 (1993) 339-352.

[14 D.S. Jayas, S. Cenkowski, S. Pabis and W.E. Muir, Review of thin layer drying and rewetting equations, Drying Technology 9 (1991) 551-558.

[15] S.T.A.R. Kajuna, V.C.K. Silayo, A. Mkenda and P.J.J. Makungu, Thin-layer drying of diced cassava roots, African Journal of Science and Technology: Science and Engineering Series 2 (2) (2001) $94-100$.

[16] C.L. Hii, C.L. Law and M. Cloke, Modelling of thin layer drying kinetics of cocoa beans during artificial and natural drying, Journal of Engineering Science and Technology 3 (1) (2008) $1-10$. 
[17] M.K. Misraand D.B. Brooker, Thin layer drying and rewetting equations for shelled yellow corn, Transactions of the ASAE 23 (1980) 1254-1260.

[18] R. Tabatabaee, D.S. Jayas and N.D.G. White, Thin-layer drying and rewetting characteristics of buckwheat, Canadian Biosystems Engineering 46 (3) (2004) 19 - 24.

[19] L.R. Verma, R.A. Bucklin, J.B. Endan and F.T. Wratten, Effects of drying air parameters on rice drying models, Transactions of the American Society of Agricultural Engineers 28 (1985) 296-301.

[20] J.F. oung, T.R. Whitaker, P.D. Blankershy, G.I.T. Brusenitz, J.M. Troeger, J.L. Stees, and N.K. Person, Effect of oven drying time on peanut moisture determination, Transactions of the American Society of Agricultural Engineers 25 (2) (1982) 491 - 495.

[21] Datafit Oakdale. Data fit version 9.05 Oakdale Engineering, Oakdale, PA 15070, USA. 2008.

[22] C. Ertekin and O. Yaldiz, Drying of eggplant and selection of a suitable thin layer drying model, Journal of Food Engineering 63 (2004) 349 - 359.

[23] M.A. Basunia and T. Abe, Thin-layer solar drying characteristics of rough rice under natural convention, Journal of Food Engineering 47 (2001) 295 - 301.

[24] J. Khazaei, Natural drying characteristics of sesame seeds, Cercetări Agronomice în Moldova XLI (3) (2008) 135.

[25] M. Kashaninejad, A. Mortazavi, A. Safekordi and L.G. Tabil, Thin-layer drying characteristics and modeling of pistachio nuts, Journal of Food Engineering 78 (2007) 98 108.

[26] J. Crank, The mathematics of diffusion, Oxford University Press, London, 1975.

[27] A.L. Gaston, R.M. Abalone, S.A. Giner and D.M. Bruce, Effect of modeling assumptions on the effective water diffusivity in wheat, Biosystems Eng. 88 (2), (2004) 175-185.

[28] R.P.F. Guine and R.M.C. Fernandes, Analysis of the drying kinetics of chestnuts, Journal of Food Engineering 76 (2006) 460-467.

[29] K. Sacilik, Effect of drying methods on thin-layer drying haracteristics of hull-less seed pumpkin (Cucurbita pepo L.), Journal of Food Engineering 79 (1) (2007) 23-30.

[30] J. Khazaei and S. Daneshmandi, Modeling of thin-layer drying kinetics of sesame seeds: mathematical and neural networks modeling, Int. Agrophysics 21 (2007) 335-348.

[31] P.S. Madamba, R.H. Driscoll and K.A. Buckle, The thin layer drying characteristics of garlic slices, Journal of Food Engineering 29 (1996) 75 - 97.

[32] D. Doulia, K. Tizia and G. Gekas, A knowledge base for apparent mass diffusivity ( $\left.\mathrm{D}_{\text {eff }}\right)$ of Foods: physical properties of food database. http://www.nelfood.com. Available at Accessed September 20, 2009. 
International Journal of Engineering Research in Africa Vol. 7

10.4028/www.scientific.net/JERA.7

Convective Thin-Layer Drying Characteristics of Sesame Seed

10.4028/www.scientific.net/JERA.7.55 
Reproduced with permission of the copyright owner. Further reproduction prohibited without permission. 